\title{
Staying Upright: Anna Flemingss Commentary on "Standing at the Waharoa” by John O’Connor
}

\author{
Anna Hinehou Fleming (Ngāpuhi, Ngāi Tūhoe)
}

\author{
PSYCHOTHERAPIST, AUCKLAND
}

\begin{abstract}
In this commentary Anna Fleming reflects upon John O'Connor's article "Standing at the Waharoa", and in particular the challenges of "staying upright" as we meet each other across our cultural differences.
\end{abstract}

\section{Whakarāpopotonga}

I tēnei kōrero ka huri a Anna Fleming ki te tuhinga "Te Tunga i te Waharoa" a Hoani O'Connor,pūtika ki te wero o te "noho tūtika" ka tūtakitahiana tātau itewhakawhitiwhititanga o ō tātau ahurei rerekētanga.

Keywords: waharoa; gateway; standing; histories; grappling; psychotherapy; Māori

Standing at the waharoa. The waharoa is a place of entrance. It is a gateway to the marae àtea, the domain of Tümatauenga. A gateway to the wharenui, the domain of Rongo. It is a place to gather with the people who we are with, and who we bring. A point to contemplate what may happen next.

In this written piece, John speaks of feeling frightened standing at this margin, and acknowledges all that this brings up for him. The pōwhiri process and subsequent meeting in the wharenui also acknowledges a breadth and depth of different connections and histories. During pōwhiri, we think of our ancestors. We think of those people who have passed on, and we also think of ourselves, those who are present on the day. On marae, we share our intentions of meeting, and sometimes historical stories which bring us to that place and time. Tears are often shed. Rage or anger may be displayed. Historical questions or hurts may be acknowledged. And this is encouraged. First and foremost, the wharenui is our ancestor and a kaitiaki. It is also a container; the place where we can gather, where we can express all of the above, and where we can do this with each other.

\footnotetext{
Fleming, A. H. (2020). Staying upright: Anna Fleming's commentary on "Standing at the waharoa" by John O’Connor. Ata: Journal of Psychotherapy Aotearoa New Zealand, 24(1), 79-8o. https://doi.org/ 10.9791/ ajpanz.2020.07
} 
Either at the waharoa or inside the wharenui, acknowledging loss and shame is extremely difficult. I acknowledge John's grappling throughout this piece with his own losses and histories and how this impacts his perspectives of living in New Zealand. As an indigenous woman with Māori and English ancestry, I feel that I can relate to that grappling. I have stood both inside and outside of wharenui and have felt less than enough in both spaces. Sometimes it has felt safer and easier to turn away, and not have to engage in the struggle. But for me, the turning away doesn't help me either, and I feel mostly stuck. The grappling, while at times often painful and difficult, at least feels like movement. What I have realised for myself recently is that stuck-ness and paralysis feels far more frightening.

In a New Zealand context, I wonder if we are beginning to grapple. Last year in particular gave us several different scenarios to grapple with. The shocking and tragic loss of Muslim lives in Christchurch in March. The high numbers of Māori babies uplifted from their whānau. The land protectors/protestors occupying the whenua at Ihumātao. These are examples from this year, and doesn't even begin to think about what we are grappling with historically. But what I do see and hear, is kōrero. On radio, on social media, on news websites. People are engaging. Sometimes the kōrero is barbed, oftentimes it's misattuned. Sometimes it's supportive. People still do turn away. But not always.

Standing at the waharoa. The name of this article is significant, particularly the word "standing". I feel as though this is something which John is encouraging us to do throughout his writing - that we stand in our own selves, our own histories, our own responses and feelings particularly as we approach Te Ao Māori, as we approach our own bicultural histories as a country. That we acknowledge as best we can, all these different facets of ourselves which come to the fore, as difficult as they may be, and stand up amongst them. That our role is to try to stay upright as best we can, rather than collapse beneath them.

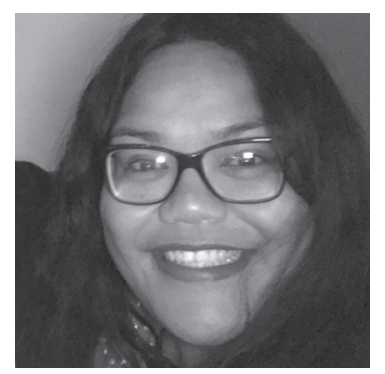

Anna Hinehou Fleming (Ngāpuhi, Ngāi Tūhoe) is a registered psychotherapist, serves on Te Rūnanga o Waka Oranga, National Collective of Māori Psychotherapy Practitioners and is a provisional member of the New Zealand Association of Psychotherapists. Anna has worked in various social and health services with individuals and whānau for over 14 years. In 2017, she graduated with a Masters of Psychotherapy with first class honours. Her therapeutic approach combines her working and personal experiences with a focus on attachment and developmental theory particularly from a Māori perspective. This focus on indigenous health informs Anna's current role as Counsellor for Māori at Auckland University of Technology, and her growing community practice in Tāmaki Makaurau. Contact details: fleming.anna@gmail.com. 